\title{
In-situ ambient quantification of monoterpenes, sesquiterpenes, and related oxygenated compounds during BEARPEX 2007: implications for gas- and particle-phase chemistry
}

\author{
N. C. Bouvier-Brown ${ }^{1}$, A. H. Goldstein ${ }^{1}$, J. B. Gilman ${ }^{2,3}$, W. C. Kuster ${ }^{2}$, and J. A. de Gouw ${ }^{2,3}$ \\ ${ }^{1}$ Department of Environmental Science, Policy, and Management, University of California, Berkeley, Berkeley, CA, USA \\ ${ }^{2}$ NOAA Earth System Research Laboratory, Boulder, CO, USA \\ ${ }^{3}$ Cooperative Institute for Research in Environmental Sciences, University of Colorado at Boulder, Boulder, CO, USA
}

Received: 27 March 2009 - Published in Atmos. Chem. Phys. Discuss.: 23 April 2009

Revised: 10 July 2009 - Accepted: 19 July 2009 - Published: 5 August 2009

\begin{abstract}
We quantified ambient mixing ratios of 9 monoterpenes, 6 sesquiterpenes, methyl chavicol, the oxygenated terpene linalool, and nopinone using an in-situ gas chromatograph with a quadrupole mass spectrometer (GC-MS). These measurements were a part of the 2007 Biosphere Effects on AeRosols and Photochemistry EXperiment (BEARPEX) at Blodgett Forest, a ponderosa pine forest in the Sierra Nevada Mountains of California. To our knowledge, these observations represent the first direct in-situ ambient quantification of the sesquiterpenes $\alpha$-bergamotene, longifolene, $\alpha$ farnesene, and $\beta$-farnesene. From average diurnal mixing ratio profiles, we show that $\alpha$-farnesene emissions are dependent mainly on temperature whereas $\alpha$-bergamotene and $\beta$-farnesene emissions are temperature- and light-dependent. The amount of sesquiterpene mass quantified above the canopy was small (averaging a total of 3.3 ppt during the day), but nevertheless these compounds contributed $7.6 \%$ to the overall ozone-olefin loss rate above the canopy. Assuming that the monoterpene-to-sesquiterpene emission rate in the canopy is similar to that observed in branch enclosure studies at the site during comparable weather conditions, and the average yield of aerosol mass from these sesquiterpenes is $10-50 \%$, the amount of sesquiterpene mass reacted within the Blodgett Forest canopy alone accounts for $6-32 \%$ of the total organic aerosol mass measured during BEARPEX. The oxygenated monoterpene linalool was also quantified for the first time at Blodgett Forest. The linalool mass contribution
\end{abstract}

Correspondence to:

N. C. Bouvier-Brown

(nbouvier@nature.berkeley.edu) was small (9.9ppt and $0.74 \mathrm{ppt}$ within and above the canopy, respectively), but it contributed $1.1 \%$ to the total ozone-olefin loss rate above the canopy. Reactive and semi-volatile compounds, especially sesquiterpenes, significantly impact the gas- and particle-phase chemistry of the atmosphere at Blodgett Forest and should be included in both biogenic volatile organic carbon emission and atmospheric chemistry models.

\section{Introduction}

Biogenic volatile organic compounds (BVOCs), including monoterpenes $\left(\mathrm{C}_{10} \mathrm{H}_{16}\right)$, sesquiterpenes $\left(\mathrm{C}_{15} \mathrm{H}_{24}\right)$, and oxygenated compounds, are important for atmospheric chemistry because they contribute to secondary organic aerosol (SOA) production and play an important role in the oxidative capacity of the atmosphere (Andreae and Crutzen, 1997; Fuentes et al., 2000). In order to understand the role of BVOCs in atmospheric chemistry, it is important to quantify their emissions, atmospheric abundance, and to understand their atmospheric oxidation.

There is evidence that a substantial fraction of gas and aerosol phase organic mass in Earth's atmosphere remains unmeasured (Goldstein and Galbally, 2007). For example, many studies indirectly suggest the presence of unmeasured highly reactive BVOCs in forest ecosystems (Di Carlo et al., 2004; Goldstein et al., 2004; Holzinger et al., 2005; Farmer and Cohen, 2008). This evidence highlights the importance of unmeasured BVOC compounds in understanding gasphase chemistry. These biogenic compounds can also significantly impact SOA formation and growth. Sesquiterpenes

Published by Copernicus Publications on behalf of the European Geosciences Union. 
have become target analytes in biogenic emission analyses because their molecular mass and reactivity make them more efficient SOA precursors than other BVOCs. The photooxidation of sesquiterpenes has been shown in smog chamber experiments to generally result in a greater aerosol yield than monoterpenes (Hoffmann et al., 1996; Griffin et al., 1999). In fact, the vapor pressure of sesquiterpene oxidation products from $\beta$-caryophyllene ozonolysis and $\alpha$-humulene photoxidation are on the order of $10^{4}-10^{5}$ times lower than the parent compound (Jaoui et al., 2003; Jaoui and Kamens, 2003), and therefore a significant fraction will partition into the particulate phase.

While analytical techniques have been well established for measuring monoterpene mixing ratios, less volatile and more reactive compounds, such as sesquiterpenes and oxygenated BVOCs, continue to present an analytical challenge for two main reasons: 1) highly reactive compounds can be too unstable to survive the typical sampling processes of solid adsorbent pre-concentration followed by thermal desorption or solvent extraction into a gas chromatograph (GC), and 2) large and low volatility compounds can stick to materials commonly used in analytical sampling (e.g. tubing, trapping material, etc.) and never reach the detector (Ortega and Helmig, 2008).

An increasing number of studies are focusing on quantifying these low volatility BVOCs using a variety of techniques (e.g. Bouvier-Brown et al., 2007; Ortega and Helmig, 2008), but they have been concentrating on emissions in branch- or leaf-level enclosures. The vegetation enclosure provides a way to measure emissions of reactive BVOCs because oxidants can be controlled. However, branch enclosure measurements do not provide direct measurements of sesquiterpene and oxygenated BVOC mixing ratios in ambient air. Typical above canopy measurement techniques have been unable to detect these highly reactive terpenes. For example, Ciccioli et al. (1999) measured $\beta$-caryophyllene emissions using branch enclosures, but were unable to detect this sesquiterpene above a Spanish orange orchard.

Sesquiterpenes in ambient air have been measured both indirectly through correlation with air ions (Bonn et al., 2007) and by measuring $m / z 205$ using proton transfer reaction mass spectrometry (PTR-MS) (Boy et al., 2008). Individual sesquiterpene compounds in ambient air have been detected using gas chromatography (Saxton et al., 2007), but not quantified. Saxton et al. (2007) collected ambient air near vegetation using thermal desorption tubes packed with adsorbents, and they subsequently analyzed the samples in a laboratory off-site. To our knowledge, we are reporting the first in-situ quantitative measurement of speciated sesquiterpenes in ambient air.

We quantified trace reactive and semi-volatile BVOCs as a part of the Biosphere Effects on AeRosols and Photochemistry EXperiment (BEARPEX) 2007. BEARPEX was a collaborative campaign that included measurements of gas phase chemicals, particle phase composition, and meteoro- logical parameters. The goal of BEARPEX was to improve the understanding of how biogenic and anthropogenic emissions affect the gas phase chemical composition as well as the formation of SOA within and above the Blodgett Forest canopy. Blodgett Forest, a ponderosa pine plantation on the western slope of the Sierra Nevada Mountains, was the site of previous studies which have concluded that there must be rapid chemical reactions occurring in the canopy (Goldstein et al., 2004; Farmer and Cohen, 2008). Unmeasured BVOCs are also thought to provide a strong ozone sink (Kurpius and Goldstein, 2003) and create a large flux of oxidation products out of the canopy (Holzinger et al., 2005). Most of the BVOCs needed to explain these observations have not been identified or quantified in the ambient air at Blodgett Forest.

We quantified the mixing ratios of 9 monoterpenes, 6 sesquiterpenes, methyl chavicol, linalool, and nopinone, present in ambient air within and above Blodgett Forest. We investigate the temporal changes in mixing ratios to elucidate controls over emissions and assess the contribution of the newly quantified BVOCs (sesquiterpenes, methyl chavicol, and linalool) on: 1) the amount of carbon mass released by the ecosystem and 2) the above canopy ozone-olefin loss rate. We also assess the sesquiterpene contribution to the total organic aerosol.

\section{Experimental methodology}

\subsection{Site description}

The 2007 Biosphere Effects on AeRosols and Photochemistry EXperiment (BEARPEX) was conducted at the Blodgett Forest Ameriflux site. This ponderosa pine plantation, owned by Sierra Pacific Industries, is located on the western slope of the Sierra Nevada Mountains of California $\left(38.90^{\circ} \mathrm{N}, 120.63^{\circ} \mathrm{W}, 1315 \mathrm{~m}\right.$ elevation). The vegetation is dominated by an overstory of ponderosa pine (Pinus ponderosa L.) trees, with an average height of $7.9 \mathrm{~m}$ in 2007 , and an understory of manzanita (Arctostaphylos spp.) and whitethorn ceanothus (Ceanothus cordulatus) shrubs. Mixing ratios and fluxes of carbon dioxide, water vapor, and ozone, along with meterological parameters, have been measured at the site since 1997, and are reported in detail elsewhere (e.g. Goldstein et al., 2000; Bauer et al., 2000). Ambient measurements of various speciated $\mathrm{C}_{2}-\mathrm{C}_{10}$ VOCs at Blodgett Forest have also been reported (Lamanna and Goldstein, 1999), including mixing ratios and fluxes of BVOCs 2-methyl-3-buten-2-ol (MBO) (e.g. Schade et al., 2000) and monoterpenes (Schade et al., 1999; Schade and Goldstein, 2003; Lee et al., 2005).

BEARPEX included two distinctly different meteorological periods (Fig. 1a). The first period from 20 August to 12 September (day of year 232-255) was characterized by warm and dry conditions (average daytime meteorological parameters: temperature $27^{\circ} \mathrm{C}$, relative humidity $26 \%$, 


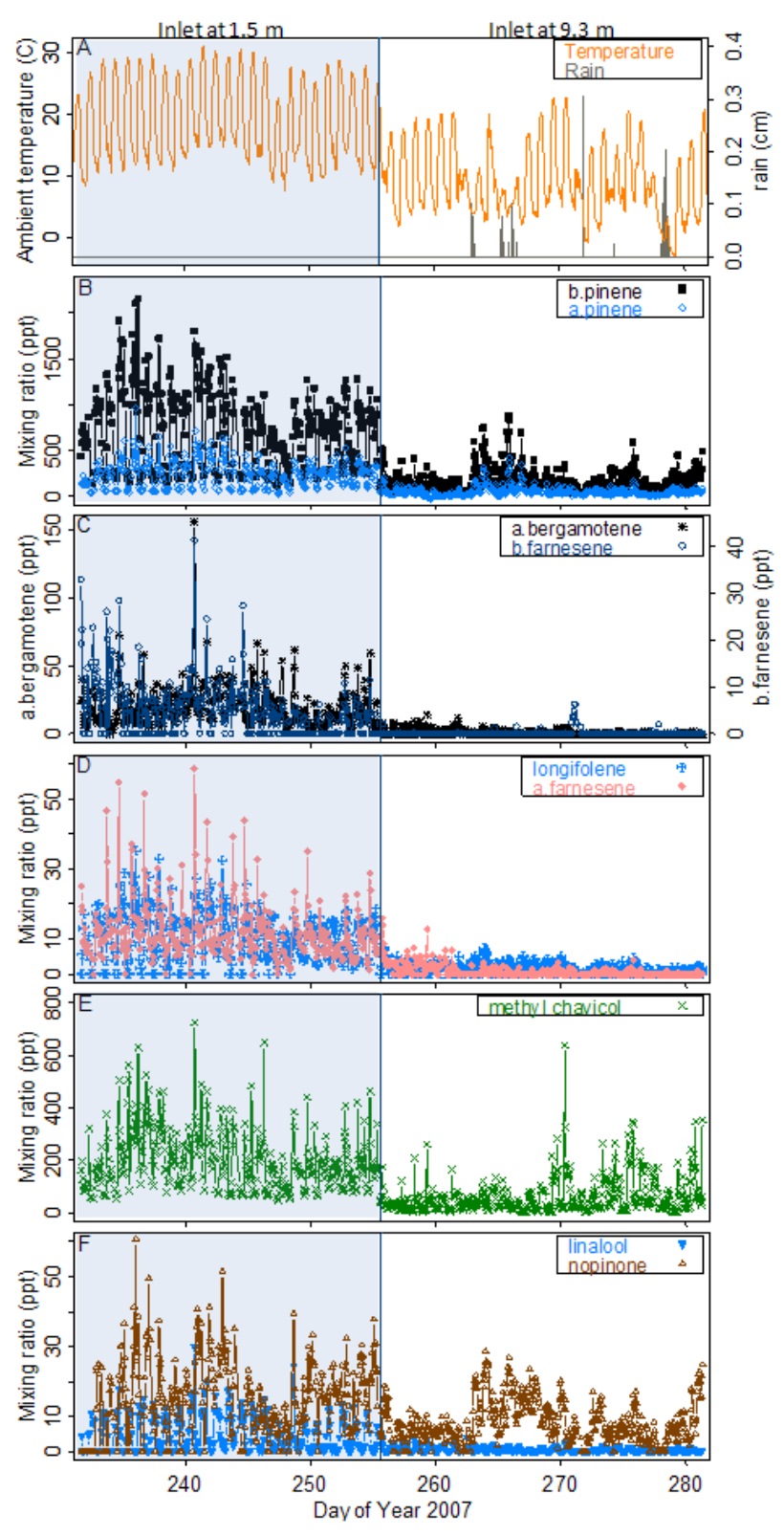

Fig. 1. Measurement time series. In all panels, the shaded region (blue) corresponds to the time when the Berkeley GC-MS was measuring at $1.5 \mathrm{~m}$ above the forest floor (day of year 231.7255.5), while the un-shaded region corresponds to the time when the Berkeley GC-MS was sampling from $9.3 \mathrm{~m}$ above the forest floor (day of year 255.6-281.3). (A) Temperature (-) and rainfall (solid grey bars). (B) Monoterpene (represented by $\beta$-pinene and $\alpha$-pinene), (C) sesquiterpenes $\alpha$-bergamotene and $\beta$-farnesene, (D) sesquiterpenes longifiolene and $\alpha$-farnesene, (E) methyl chavicol, (F) linalool and nopinone mixing ratio time series.

and maximum photosynthetically active radiation (PAR) $1410 \mu \mathrm{mol} \mathrm{m}^{-2} \mathrm{~s}^{-1}$ ). The second period from 13 September to 10 October (day of year 256-283) was characterized by cool and wet conditions (average daytime meteorological

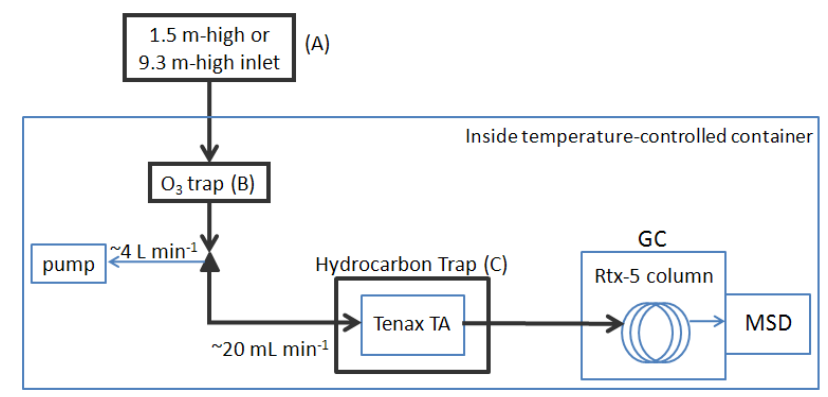

Fig. 2. Schematic of the Berkeley GC-MS instrument set-up. (A) All tubing and fittings prior to the GC oven (indicated by thick black lines) were made of Silcosteel (Restek) and actively heated (to $\sim 50^{\circ} \mathrm{C}$ ). (B) $1 \mu \mathrm{m}$ pore size Pall $\mathrm{A} / \mathrm{E}$ glass fiber filter coated with sodium thiosulfate. (C) Hydrocarbon trap adsorbent (Tenax TA) remained at ambient temperature during the 30-min collection, then heated to $220^{\circ} \mathrm{C}$ within $10 \mathrm{~s}$ to inject the sample into the helium carrier gas flowing into the GC oven.

parameters: temperature $15^{\circ} \mathrm{C}$, relative humidity $49 \%$, and PAR $1010 \mu \mathrm{mol} \mathrm{m}^{-2} \mathrm{~s}^{-1}$ ).

\subsection{Instrumental setup}

Monoterpenes, methyl chavicol, and sesquiterpenes were quantified using an in-situ gas chromatograph with a quadrupole mass spectrometer (Berkeley GC-MS; Fig. 2). Ambient air was pulled down through a $6.35 \mathrm{~mm}$ OD (4.57 mm ID) inlet at $4 \mathrm{~L} \mathrm{~min}^{-1}$. As the inlet entered the temperature-controlled container, the air sample passed through a $1 \mu \mathrm{m}$ pore size Pall A/E glass fiber filter (VWR, Ann Arbor, MI) coated with sodium thiosulfate (SigmaAldrich, St. Louis, MO), following Pollmann et al. (2005), to remove ozone. The filter, housed in a stainless steel filter holder (Cole Parmer, Vernon Hills, IL), was also used to scrub out particulate matter. After passing through the ozone filter, the amount of ozone in the airstream was measured with an Ozone Monitor (Model 202, 2B Technologies), and to ensure effectiveness, the filter was changed at least once per day.

BVOCs in a $20 \mathrm{~mL} \mathrm{~min}^{-1}$ subsample were collected on a hydrocarbon preconcentration trap packed with Tenax TA (Sigma-Aldrich). With ambient water vapor present in the sample, the hydrocarbon trap remained at ambient temperature during sample collection to prevent water accumulation in the adsorbent bed. After a 30-min collection, the hydrocarbon trap was heated to $220^{\circ} \mathrm{C}$ within $10 \mathrm{~s}$ to thermally desorb the trapped compounds into the ultra high purity helium carrier gas and transfer them to the head of a chromatographic column $(30 \mathrm{~m} \times 0.25 \mathrm{~mm} \times 0.25 \mu \mathrm{m}$ phase thickness, Rtx-5; Restek). The GC oven temperature was held at $43^{\circ} \mathrm{C}$ for $4.25 \mathrm{~min}$, increasing to $160^{\circ} \mathrm{C}$ at $5^{\circ} \mathrm{C} \mathrm{min}^{-1}$, then to $220^{\circ} \mathrm{C}$ at $10^{\circ} \mathrm{C} \mathrm{min}{ }^{-1}$, and held at this temperature for $11.75 \mathrm{~min}$. 
Table 1. Dominant ion used to quantify each BVOC and average ( \pm standard deviation) mixing ratios measured during BEARPEX. Numbers in italics indicate that the average value is below the detection limit, while "NA" denotes that all values were below the detection limit. Average temperature and PAR measured during each measurement time period are also noted.

\begin{tabular}{|c|c|c|c|c|c|}
\hline & & Day & Night & Day & Night \\
\hline Dates & & 20 Aug-12 Sept & 20 Aug-12 Sept & 13 Sept-10 Oct & 13 Sept-10 Oct \\
\hline Time (PST) & & 10:00-17:00 & 19:00-06:00 & 10:00-17:00 & 19:00-06:00 \\
\hline Average temperature $\left({ }^{\circ} \mathrm{C}\right)$ & & $26.4 \pm 2.4$ & $12.8 \pm 2.6$ & $14.8 \pm 5.1$ & $5.2 \pm 2.9$ \\
\hline Average PAR $\left(\operatorname{molm}^{-2} \mathrm{~s}^{-1}\right)$ & & $1356 \pm 454$ & $24 \pm 83$ & $970 \pm 512$ & $11 \pm 44$ \\
\hline BVOC measurement height & & $1.5 \mathrm{~m}$ & $1.5 \mathrm{~m}$ & $9.3 \mathrm{~m}$ & $9.3 \mathrm{~m}$ \\
\hline BVOC sample size & & $N=105$ & $N=227$ & $N=152$ & $N=311$ \\
\hline BVOC & Ion & (ppt) & $(\mathrm{ppt})$ & (ppt) & $(\mathrm{ppt})$ \\
\hline$\beta$-pinene & 93 & $311 \pm 250$ & $915 \pm 301$ & $118 \pm 58$ & $170 \pm 13$ \\
\hline 3-carene & 93 & $210 \pm 163$ & $612 \pm 166$ & $54 \pm 33$ & $75 \pm 82$ \\
\hline$\alpha$-pinene & 93 & $104 \pm 72$ & $313 \pm 121$ & $39 \pm 24$ & $60 \pm 60$ \\
\hline limonene ( $+\beta$-phellandrene) & 93 & $76 \pm 46$ & $223 \pm 66$ & $19 \pm 9$ & $33 \pm 27$ \\
\hline myrcene & 93 & $10 \pm 5$ & $20 \pm 6$ & $2.91 \pm 1.07$ & $2.29 \pm 1.86$ \\
\hline camphene & 93 & $5.91 \pm 4.39$ & $21 \pm 11$ & $0.82 \pm 1.00$ & $3.25 \pm 3.18$ \\
\hline terpinolene & 93 & $3.52 \pm 2.22$ & $4.89 \pm 2.61$ & $0.37 \pm 0.59$ & $0.17 \pm 0.63$ \\
\hline$\gamma$-terpinene & 93 & $1.46 \pm 2.25$ & $4.10 \pm 2.71$ & NA & NA \\
\hline$\alpha$-terpinene & 93 & NA & NA & NA & NA \\
\hline Total monoterpenes & & 722 & 2113 & 234 & 344 \\
\hline methyl chavicol & 148 & $127 \pm 99$ & $212 \pm 89$ & $90.1 \pm 60.4$ & $26.5 \pm 20.0$ \\
\hline linalool & 93 & $9.90 \pm 3.36$ & $0.76 \pm 1.48$ & $0.74 \pm 0.89$ & NA \\
\hline nopinone & 83 & $7.49 \pm 7.96$ & $19.4 \pm 10.3$ & $6.73 \pm 4.84$ & $9.05 \pm 6.63$ \\
\hline$\alpha$-bergamotene & 93 & $24.1 \pm 11.2$ & $13.2 \pm 7.7$ & $1.84 \pm 2.22$ & $0.40 \pm 1.01$ \\
\hline longifolene & 161 & $3.61 \pm 3.56$ & $14.7 \pm 5.3$ & $0.60 \pm 0.81$ & $1.78 \pm 1.61$ \\
\hline$\alpha$-farnesene & 93 & $9.42 \pm 8.19$ & $12.2 \pm 5.8$ & $0.87 \pm 1.47$ & $0.53 \pm 1.37$ \\
\hline$\beta$-farnesene & 69 & $5.97 \pm 5.59$ & $3.35 \pm 4.74$ & NA & $0.13 \pm 0.72$ \\
\hline SQT 9 & 93 & $0.91 \pm 1.71$ & $0.23 \pm 0.83$ & NA & NA \\
\hline SQT 10 & 93 & $0.52 \pm 1.84$ & $0.34 \pm 1.12$ & NA & NA \\
\hline Total sesquiterpenes & & 44.5 & 43.9 & 3.3 & 2.9 \\
\hline
\end{tabular}

The mass spectrometer was operated in single ion mode and the quantification ions are listed in Table 1.

Modifications to the original set-up described by Millet et al. (2005) were made to minimize the potential for low volatility compounds to be lost through condensation or adsorption (Fig. 2). To reduce sample loss due to condensation in the sample pathway, all tubing and fittings prior to the GC oven were made of Silcosteel (Restek) and heated to $\sim 50^{\circ} \mathrm{C}$ using heating cables and ropes (Omega Engineering Stamford, CT). The metal tubing allows for even heat dispersal and the internally passivated surface minimizes wall reactions and subsequent losses. Helmig et al. (2004) successfully recovered sesquiterpene standards after heating the valves and tubing downstream of preconcentration adsorbent cartridges to $50^{\circ} \mathrm{C}$, and due to the limits of the instrument set-up, this was the highest achievable temperature.

Two heated sample inlets were used at different times during the experiment. From 19 August through the morning of 12 September (day of year 232-255), the sample was drawn from $1.5 \mathrm{~m}$ above the canopy floor (Fig. 1) through $\sim 11 \mathrm{~m}$ of tubing (giving $\sim 2.9 \mathrm{~s}$ residence time) into a temperaturecontrolled container. From the afternoon of 12 September through 8 October (day of year 255-281), biogenic VOCs were pulled through $\sim 18 \mathrm{~m}$ of tubing from $9.3 \mathrm{~m}$ above the forest floor (giving $\sim 4.5 \mathrm{~s}$ residence time) (Fig. 1). This height corresponds to $\sim 2 \mathrm{~m}$ above the mean forest canopy height. Measurements at the different heights coincided with the two distinct meteorological periods during BEARPEX.

Blanks and standards were run at least once per day. A zero air blank for the system was created by flowing ambient air through a heated platinum catalyst (Millet et al., 2005). Gas standards (Scott Marrin Inc. and Apel \& Riemer) containing one or more of the dominant monoterpenes found at the field site ( $\alpha$-pinene, $\beta$-pinene, 3 -carene, and limonene) were used for monoterpene calibrations. These ppm-level standards were diluted dynamically into the larger $\sim 4 \mathrm{~L} \mathrm{~min}^{-1}$ zero air flow. The sesquiterpenes and oxygenated compounds are known to be unstable 
Table 2. Ions used for quantification and percent recovery from liquid standard injections. Sample size $N=1$ and $N=10$ for the $1.5 \mathrm{~m}$ and $9.3 \mathrm{~m}$ inlet, respectively. BVOCs are listed in order of increasing chemical reactivity.

\begin{tabular}{lrrrrr}
\hline BVOC & $\begin{array}{r}\text { Quantified } \\
\text { ion }\end{array}$ & $\begin{array}{r}\% \text { recovery } \\
1.5 \mathrm{~m} \text { inlet }\end{array}$ & $\begin{array}{r}\% \text { recovery } \\
9.3 \mathrm{~m} \text { inlet }\end{array}$ & $\tau_{\mathrm{OH}^{\mathrm{a}}}{ }^{\mathrm{a}}(\mathrm{min})$ & $\tau_{\mathrm{O}_{3}}{ }^{\mathrm{b}}(\mathrm{min})$ \\
\hline nopinone & 83 & 101 & $92 \pm 15$ & $180^{\mathrm{d}}$ & $2.8 \times 10^{6^{\mathrm{d}}}$ \\
longifolene & 161 & 81 & $66 \pm 6$ & 64 & $2.8 \times 10^{4}$ \\
verbenone & 91 & 85 & $77 \pm 34$ & $38^{\mathrm{c}}$ & $190^{\mathrm{c}}$ \\
methyl chavicol & 148 & 19 & $108 \pm 64$ & $57^{\mathrm{c}}$ & $926^{\mathrm{c}}$ \\
$\alpha$-cedrene & 119 & 110 & $71 \pm 6$ & 47 & 504 \\
$\alpha$-copaene & 119 & 105 & $83 \pm 12$ & 33 & 89 \\
aromadendrene & 91 & 119 & $84 \pm 15$ & $490^{\mathrm{c}}$ & 2 \\
linalool & 93 & 87 & $58 \pm 14$ & 19 & 33 \\
$\beta$-caryophyllene & 93 & 26 & $19 \pm 27$ & 15 & 1 \\
$\alpha$-humulene & 93 & 22 & $19 \pm 27$ & 10 & 1 \\
\hline
\end{tabular}

a,b all rate constants from Atkinson and Arey (2003) and references within, except where noted

a $[\mathrm{OH}]=5.4 \times 10^{6} \mathrm{molec} \mathrm{cm}^{-3}$ (W. Brune, J. Mao, personal communication, 2008)

$\mathrm{b}\left[\mathrm{O}_{3}\right]=1.18 \times 10^{12}$ molec $^{-3}$

c rate constants estimated from Environmental Protection Agency's Estimation Program Interface Suite (US EPA AOPWIN, 2000)

$\mathrm{d}$ rate constants from Calogirou et al. (1999)

${ }^{\mathrm{e}} k_{\mathrm{O}_{3}}$ estimated from Pollmann et al. (2005)

in a gas standard (e.g. Helmig et al., 2003; Ortega and Helmig, 2008), so liquid standards were made from diluting 6 sesquiterpenes ( $\alpha$-cedrene, $\alpha$-copaene, longifolene, $\beta$ caryophyllene, $\alpha$-humulene, aromadendrene), 3 oxygenated terpenes (linalool, nopinone, verbenone), and methyl chavicol (a.k.a. 4-allyanisole or estragole) in cyclohexane. All chemicals have $>97 \%$ purity and were obtained from SigmaAldrich or from Fluka Chemicals through Sigma-Aldrich. Small amounts $(0.25-1.0 \mu \mathrm{L})$ of these liquid standards were manually injected with a microliter syringe (Restek) into a $100-200 \mathrm{~mL} \mathrm{~min}^{-1}$ stream of nitrogen, where the injector port was heated to $100^{\circ} \mathrm{C}$. Concentrations ranged from 2$63 \mathrm{ppt}$ for sesquiterpenes and 3-94 ppt for oxygenated terpenes and methyl chavicol. This standard flow was then subsampled and collected through the same tubing and at the same flow rate as an ambient sample. To ensure no liquid standard condensed in the sampling lines, subsequent blank nitrogen samples were also collected through the calibration pathway. The daily standard injections were also used to quantify the drift in instrument response during the study period. The final time-dependent response factor applied to each analyte accounted for the -0.51 to $-1.4 \%$ per day instrument drift and concentration-dependent response. The ions used for quantification (in standards (see Table 2) and samples (see Table 1)) were the dominant ions for each compound, with the exception of $\beta$-farnesene and aromadendrene, which were 3rd and 2nd most abundant, respectively. Each of these dominant ions averaged $8 \pm 3 \%$ of the total fragmentation abundance. Therefore, sesquiterpene peak areas not corresponding to a liquid standard were calibrated using the average response of the dominant ions of sesquiterpene standards.
The detection limits are defined as the amount of standard required to create a peak 3 times the baseline noise. The average detection limit for monoterpenes, oxygenated terpenes, sesquiterpenes, and methyl chavicol was $1.26 \pm 0.12$ (mean \pm standard deviation), $2.51 \pm 0.22,1.86 \pm 0.12$, and $1.96 \pm 0.45 \mathrm{ppt}$, respectively. Average mixing ratios for each BVOC quantified during BEARPEX are listed in Table 1. The quoted measurement uncertainty includes reproducibility, accuracy of the calibration slope, sampling and standard addition mass flow measurements, and the accuracy of the standards. The average uncertainty for monoterpenes, oxygenated terpenes, sesquiterpenes, and methyl chavicol was $18 \%, 26 \%, 23 \%$, and $27 \%$, respectively.

To assess inlet line losses of the semi-volatile oxygenated compounds and sesquiterpenes, liquid standards were injected at the sample inlet and diluted with ambient air. Percent recovery for each standard is listed in Table 2. Most standards are efficiently recovered, with $\beta$-caryophyllene and $\alpha$-humulene as notable exceptions. There were no traces of $\beta$-caryophyllene or $\alpha$-humulene in 6 out of the 10 tests using the longer $9.3 \mathrm{~m}$ inlet. We did not correct the data for line losses, so the reported measurements are lower limits for some compounds.

\subsection{NOAA GC-MS measurements}

Volatile $\mathrm{C}_{2}-\mathrm{C}_{10}$ organic compounds, in particular isoprene, methacrolein (MACR), methyl vinyl ketone (MVK), 2methyl-3-buten-2-ol (MBO), 3-methylfuran, propene, and ethene, were quantified using a gas chromatograph with mass spectrometer detector (NOAA GC-MS). The sample acquisition procedure is described in detail by Goldan et al. (2004), 

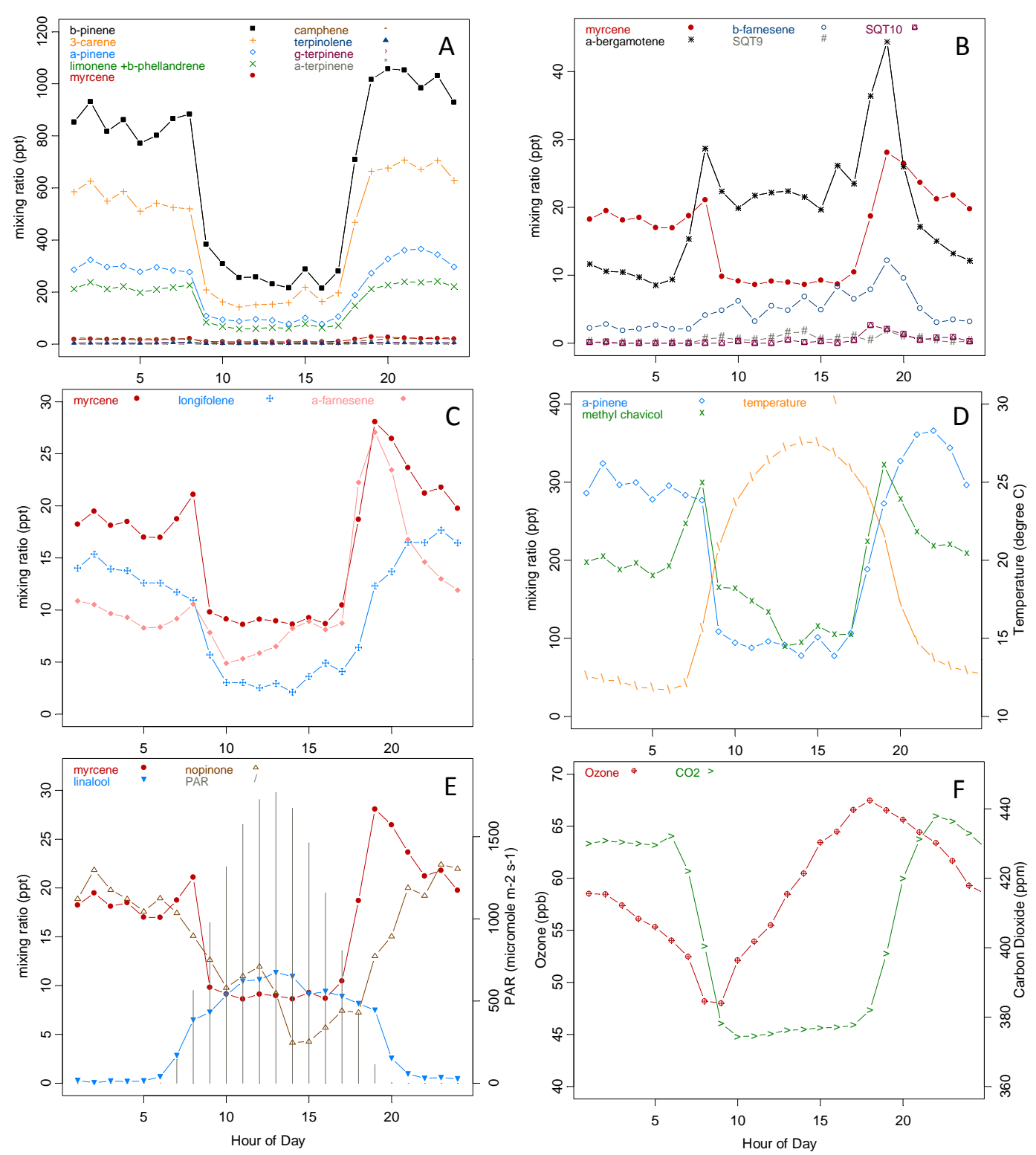

Fig. 3. The number of data points averaged each hour was $16.5 \pm 3.5$ (variability stems from the exclusion of data when standards or blanks were sampled). (A) Monoterpene average diurnal profiles measured at $1.5 \mathrm{~m}$. (B) Average diurnal profiles of sesquiterpenes $\alpha$-bergamotene, $\beta$-farnesene, and unidentified SQT9 and SQT10, as compared to myrcene, measured at $1.5 \mathrm{~m}$. (C) Average diurnal profiles of sesquiterpenes $\alpha$-farnesene and longifolene, as compared to myrcene, measured at $1.5 \mathrm{~m}$. (D) Methyl chavicol average diurnal profile, as compared to $\alpha$-pinene at $1.5 \mathrm{~m}$. The temperature diurnal cycle is measured at $4.9 \mathrm{~m}$ above the ground. (E) Linalool and nopinone average diurnal profiles, as compared to myrcene, at $1.5 \mathrm{~m}$. Photosynthetically active radiation (PAR) was measured at $15 \mathrm{~m}$ above the ground and its diurnal cycle is represented by solid grey bars. (F) Average diurnal profiles of ozone and carbon dioxide measured at $12.5 \mathrm{~m}$ and $1.2 \mathrm{~m}$ above the ground, respectively.

and more recent modifications were briefly described by Bouvier-Brown et al. (2009b). The $12 \mathrm{~m} 6.35 \mathrm{~mm}$ OD PFA inlet of this system was located at $9.3 \mathrm{~m}$ above the canopy floor for three days (24 September-27 September, day of year 267-270). Two 5 min samples were acquired concurrently every $30 \mathrm{~min}$. Light alkanes and alkenes $\left(\mathrm{C}_{2}-\mathrm{C}_{5}\right)$ were separated on a $\mathrm{KCl}$ washed Alumina column. The heavier species $\left(\mathrm{C}_{2}-\mathrm{C}_{10}\right)$ were cryofocused and then separated using a metal MXT-624 column (Restek). All VOCs were detected using a quadrupole mass spectrometer (Agilent 5973). 
Table 3. Structures and reactivity of all BVOCs measured using the Berkeley GC-MS instrument during BEARPEX.

\begin{tabular}{|c|c|c|c|c|c|c|c|}
\hline Compound & Structure & $\begin{array}{c}\mathbf{k}_{\mathrm{OH}} \\
k_{\mathrm{O} 3} \\
k_{\mathrm{NO} 3} \\
\left(\mathrm{~cm}^{3} \mathrm{molec}^{-1} \mathrm{~s}^{-1}\right)\end{array}$ & $\begin{array}{l}\tau_{\mathrm{OH}}{ }^{a} \\
\tau_{\mathrm{O} 3}{ }^{3} \\
\tau_{\mathrm{NO} 3}{ }^{c} \\
(\min )\end{array}$ & Compound & Structure & $\begin{array}{c}\mathbf{k}_{\mathrm{OH}} \\
\mathrm{k}_{\mathrm{O} 3} \\
\mathrm{k}_{\mathrm{NO3}} \\
\left(\mathrm{cm}^{3} \mathrm{molec}^{-1} \mathrm{~s}^{-1}\right)\end{array}$ & $\begin{array}{l}\tau_{\mathrm{OH}^{a}}{ }^{\mathrm{a}} \\
\tau_{\mathrm{O} 3}{ }^{\mathrm{b}} \\
\tau_{\mathrm{NO} 3}{ }^{\mathrm{c}} \\
\text { (min) }\end{array}$ \\
\hline $\begin{array}{l}\text { longifolene } \\
\left(\mathrm{C}_{15} \mathrm{H}_{24}\right)\end{array}$ & & $\begin{array}{l}4.8 \times 10^{-11} \\
5.0 \times 10^{-19} \\
6.9 \times 10^{-13}\end{array}$ & $\begin{array}{c}60 \\
2.8 \times 10^{4} \\
1150\end{array}$ & $\begin{array}{l}\text { myrcene } \\
\left(\mathrm{C}_{10} \mathrm{H}_{16}\right)\end{array}$ & & $\begin{array}{l}2.1 \times 10^{-10} \\
4.7 \times 10^{-16} \\
1.1 \times 10^{-11}\end{array}$ & $\begin{array}{l}15 \\
30 \\
70\end{array}$ \\
\hline $\begin{array}{c}\alpha \text {-bergamotene } \\
\left(\mathrm{C}_{15} \mathrm{H}_{24}\right)\end{array}$ & & $\begin{array}{c}1.8 \times 10^{-10 \mathrm{~d}} \\
8.6 \times 10^{-16} \mathrm{~d} \\
?\end{array}$ & $\begin{array}{l}17 \\
16\end{array}$ & $\begin{array}{l}\text { camphene } \\
\left(\mathrm{C}_{10} \mathrm{H}_{16}\right)\end{array}$ & & $\begin{array}{l}5.34 \times 10^{-11} \\
9.19 \times 10^{-19} \\
6.54 \times 10^{-13}\end{array}$ & $\begin{array}{c}58 \\
1.5 \times 10^{4} \\
1210\end{array}$ \\
\hline $\begin{array}{c}\alpha \text {-farnesene } \\
\left(\mathrm{C}_{15} \mathrm{H}_{24}\right)\end{array}$ & & $\begin{array}{c}3.2 \times 10^{-10} \mathrm{~d} \\
1.0 \times 10^{-15} \mathrm{~d} \\
?\end{array}$ & $\begin{array}{l}10 \\
14\end{array}$ & $\begin{array}{l}\text { terpinolene } \\
\left(\mathrm{C}_{10} \mathrm{H}_{16}\right)\end{array}$ & & $\begin{array}{l}2.3 \times 10^{-10} \\
1.9 \times 10^{-15} \\
9.5 \times 10^{-11}\end{array}$ & $\begin{array}{c}13 \\
7 \\
8\end{array}$ \\
\hline $\begin{array}{c}\beta \text {-farnesene } \\
\left(\mathrm{C}_{15} \mathrm{H}_{24}\right)\end{array}$ & & $\begin{array}{c}2.8 \times 10^{-10} \mathrm{~d} \\
4.01 \times 10^{-16} \mathrm{e} \\
?\end{array}$ & $\begin{array}{l}11 \\
35\end{array}$ & $\begin{array}{c}\gamma \text {-terpinene } \\
\left(\mathrm{C}_{10} \mathrm{H}_{16}\right)\end{array}$ & & $\begin{array}{l}1.8 \times 10^{-10} \\
1.4 \times 10^{-16} \\
3.3 \times 10^{-11}\end{array}$ & $\begin{array}{c}17 \\
100 \\
20\end{array}$ \\
\hline $\begin{array}{l}\alpha \text {-pinene } \\
\left(\mathrm{C}_{10} \mathrm{H}_{16}\right)\end{array}$ & & $\begin{array}{l}5.3 \times 10^{-11} \\
8.4 \times 10^{-17} \\
6.1 \times 10^{-12}\end{array}$ & $\begin{array}{c}58 \\
170 \\
130\end{array}$ & $\begin{array}{c}\alpha \text {-terpinene } \\
\left(\mathrm{C}_{10} \mathrm{H}_{16}\right)\end{array}$ & & $\begin{array}{l}3.6 \times 10^{-10} \\
2.1 \times 10^{-14} \\
1.3 \times 10^{-10}\end{array}$ & $\begin{array}{c}9 \\
0.7 \\
6\end{array}$ \\
\hline $\begin{array}{c}\beta \text {-pinene } \\
\left(\mathrm{C}_{10} \mathrm{H}_{16}\right)\end{array}$ & & $\begin{array}{l}7.7 \times 10^{-11} \\
1.5 \times 10^{-17} \\
2.5 \times 10^{-12}\end{array}$ & $\begin{array}{c}40 \\
940 \\
320\end{array}$ & $\begin{array}{l}\text { methyl chavicol } \\
\qquad\left(\mathrm{C}_{10} \mathrm{H}_{12} \mathrm{O}\right)\end{array}$ & & $\begin{array}{c}5.4 \times 10^{-11} \mathrm{~d} \\
1.2 \times 10^{-17} \mathrm{~d} \\
?\end{array}$ & $\begin{array}{c}57 \\
926\end{array}$ \\
\hline $\begin{array}{l}\text { 3-carene } \\
\left(\mathrm{C}_{10} \mathrm{H}_{16}\right)\end{array}$ & & $\begin{array}{l}8.7 \times 10^{-11} \\
3.7 \times 10^{-17} \\
9.5 \times 10^{-12}\end{array}$ & 380 & $\begin{array}{l}\text { linalool } \\
\left(\mathrm{C}_{10} \mathrm{H}_{18} \mathrm{O}\right)\end{array}$ & & $\begin{array}{l}1.6 \times 10^{-10} \\
4.3 \times 10^{-16} \\
1.1 \times 10^{-11}\end{array}$ & $\begin{array}{l}19 \\
33 \\
70\end{array}$ \\
\hline $\begin{array}{l}\text { limonene } \\
\left(\mathrm{C}_{10} \mathrm{H}_{16}\right)\end{array}$ & & $\begin{array}{l}1.7 \times 10^{-10} \\
2.0 \times 10^{-16} \\
1.3 \times 10^{-11}\end{array}$ & 18 & $\begin{array}{l}\text { nopinone } \\
\left(\mathrm{C}_{9} \mathrm{H}_{14} \mathrm{O}\right)\end{array}$ & & $\begin{array}{l}1.7 \times 10^{-11} f \\
<5 \times 10^{-21} f \\
<2 \times 10^{-15} f\end{array}$ & $\begin{array}{c}180 \\
3 \times 10^{6} \\
4 \times 10^{5}\end{array}$ \\
\hline
\end{tabular}

a,b,c All data from Atkinson and Arey (2003) and references therein except where noted

a $[\mathrm{OH}]=5.4 \times 10^{6} \mathrm{molec} \mathrm{cm}^{-3}(0.25 \mathrm{ppt})$ (W. Brune, J. Mao, personal communication, 2008)

$\mathrm{b}\left[\mathrm{O}_{3}\right]=1.18 \times 10^{12} \mathrm{molec} \mathrm{cm}^{-3}(55 \mathrm{ppb})$

c $\left[\mathrm{NO}_{3}\right]=1.2 \times 10^{7}$ molec $\mathrm{cm}^{-3}$ (1 ppt) (R. Cohen, personal communication, 2008)

d estimated from Environmental Protection Agency's Estimation Program Interface Suite (US EPA AOPWIN, 2000)

e from Kourtchev et al. (2009)

$\mathrm{f}$ from Calogirou et al. (1999)

\section{Results}

Monoterpene, sesquiterpene, methyl chavicol, linalool, and nopinone mixing ratio data are shown as both time series and average diurnal profiles. Timelines of BVOC mixing ratios over the 7-week BEARPEX campaign are presented in conjunction with temperature and rainfall patterns (Fig. 1). The diurnal profile data focus on ambient mixing ratios measured from the $1.5 \mathrm{~m}$ inlet (Fig. 3). For comparison, average day and night mixing ratios from both inlets are found in Table 1 . For reference, chemical structures of all quantified BVOCs are listed in Table 3.

\subsection{Monoterpenes}

Using the GC-MS system, 9 monoterpenes were separated; these included: $\beta$-pinene, $\alpha$-pinene, 3 -carene, limonene $+\beta$ phellandrene, myrcene, camphene, terpinolene, $\gamma$-terpinene, and $\alpha$-terpinene. The monoterpene mixing ratio timelines (Fig. 1b), represented by $\beta$-pinene and $\alpha$-pinene, emphasize their dependence on temperature and measurement height. A significant decrease in ambient mixing ratios is observed with the simultaneous decrease in ambient temperature and increase in inlet height. Monoterpene mixing ratios at Blodgett Forest are also greatly enhanced by precipitation. Even 
at low temperatures, high monoterpene mixing ratios are observed immediately following rain events, especially after the first storm of the year (day of year 263-266). Humidity effects on monoterpene emissions have been previously observed at this site by Schade et al. (1999). The dominant monoterpene at Blodgett Forest is $\beta$-pinene (Fig. 3a); on average, it accounts for $47 \%$ of the total monoterpene mass. $97 \%$ of the monoterpene mass is emitted as a combination of $\beta$-pinene, $\alpha$-pinene, 3 -carene, and limonene $+\beta$ phellandrene.

\subsection{Sesquiterpenes}

We report the first in-situ direct quantification of speciated sesquiterpenes, including $\alpha$-bergamotene, longifolene, $\alpha$-farnesene, $\beta$-farnesene, and two unidentified sesquiterpene compounds (SQT 9 and 10), in ambient air. The sesquiterpene mixing ratio timelines (Fig. 1c, d) show significant decreases with lower temperatures and increased measurement height. The dominant sesquiterpene in the daytime was $\alpha$-bergamotene (Table 1, Fig. 3b), just as it was in the ponderosa pine branch enclosures at Blodgett Forest (Bouvier-Brown et al., 2009a). Longifolene was the dominant sesquiterpene at night (Table 1, Fig. 3c). All identified sesquiterpenes were quantified at ambient mixing ratios similar to that of the monoterpene myrcene (Fig. 3b, c). $\beta$ farnesene, SQT 9, and SQT 10 are not detected at $9.3 \mathrm{~m}$ (Table 1).

\subsection{Oxygenated compounds}

We report abundant mixing ratios of methyl chavicol. Methyl chavicol, an important biogenic emission from ponderosa pine trees, was recently characterized by Bouvier-Brown et al. (2009b). The methyl chavicol mixing ratio time series (Fig. 1e) generally mirrors that of monoterpenes and sesquiterpenes because there is a significant decrease in average mixing ratios with the simultaneous decrease in temperature and increase in sampling height. On the other hand, unlike the terpenes, methyl chavicol emissions are also significantly enhanced a few days following rain events (see also Bouvier-Brown et al., 2009b). Methyl chavicol mixing ratios are significant, for they are comparable to major monoterpenes such as $\alpha$-pinene (Table 1, Fig. 3d).

We also report the first measurements of linalool at Blodgett Forest. Linalool is an oxygenated terpene emitted in large amounts from other sites, such as Mediterranean forests (Owen et al., 2001) and a Spanish orange orchard (Ciccioli et al., 1999). The mixing ratio time series (Fig. 1f) emphasizes linalool's dependence on temperature and inlet height. Only a small amount of linalool is quantified at Blodgett Forest. At solar noon, maximum linalool mixing ratios are comparable to the simultaneous minimum myrcene mixing ratio (Fig. 3e).
We report the first GC-MS measurements of nopinone, the primary oxidation product of $\beta$-pinene, at Blodgett. This relationship is highlighted by the way nopinone's mixing ratios mirror that of its precursor $\beta$-pinene (Fig. 1f). In an average diurnal profile, nopinone shows decreasing mixing ratios throughout the daytime reaching a minimum at 14:0019:00 PST (Fig. 3e). A similar pattern was observed by Holzinger et al. (2005) at this site using proton-transfer mass spectrometery (PTR-MS) $(\mathrm{m} / \mathrm{z} 139)$ but at much higher mixing ratios. The PTR-MS $m / z 139$ may include fragments of larger compounds. Holzinger et al. (2005) attributed the afternoon mixing ratio decrease to phase partitioning from the gas to the particle phase. Nopinone mixing ratios at BEARPEX are comparable to that of myrcene.

\section{Discussion}

\subsection{BVOC emission models}

BVOC emissions are typically modeled with either temperature-dependent or temperature- and light-dependent algorithms (e.g. Guenther et al., 1993). BVOC mixing ratio patterns in the average diurnal profiles provide clues about the emission drivers. Most emission models assume the majority, if not all, of monoterpenes are emitted as a function of temperature (e.g. Levis et al., 2003; Heald et al., 2008; Sakulyanontvittaya et al., 2008), but due to limited studies, sesquiterpene data is either eliminated from global models or vast assumptions have to be made about their emission drivers. For example, Sakulyanontvittaya et al. (2008) assume that $50 \%$ of sesquiterpene emissions are driven by temperature and $50 \%$ are also influenced by light. We will determine the dominant emission driver(s) for monoterpenes, four sesquiterpenes ( $\alpha$-farnesene, longifolene, $\alpha$-bergamotene, and $\beta$-farnesene), methyl chavicol, and linalool in the next two sections; our conclusions generally support the assumptions made by Sakulyanontvittaya et al. (2008). No mixing ratio pattern was discernable for SQT 9 and SQT 10 because they were often below the detection limit.

\subsubsection{Temperature-dependent emissions}

The monoterpene average diurnal patterns indicate that their emissions are driven by temperature because elevated mixing ratios occur at night and in the morning (07:00-08:00 PST) (Fig. 3a). These times occur when temperatures are warm enough to induce emissions and both oxidation and vertical mixing are slow (Fig. 3f). In Fig. 3f, oxidation is represented by ozone mixing ratios and carbon dioxide mixing ratios are used as a proxy for vertical mixing. This pattern has been shown at Blodgett Forest previously (e.g. Holzinger et al., 2005). Our data suggest that some, but not all, sesquiterpene emissions at Blodgett Forest can be modeled as temperature-dependent processes. For example, the 
mixing ratios of sesquiterpene $\alpha$-farnesene exhibit a similar diurnal pattern to that of the monoterpene mycrene (Fig. 3c), with higher mixing ratios at night than during the day. Since we know that $\alpha$-farnesene and myrcene have similar sources (Bouvier-Brown et al., 2009a) and comparable loss processes with reaction rates of similar magnitude (Table 3), we infer that temperature is also the main driver of $\alpha$-farnesene emissions. Similarly, longifolene, the dominant sesquiterpene present at night (Fig. 3c), is also likely driven by temperature, but further branch enclosure studies are required to definitively determine the emission drivers. As a consequence of its relatively long lifetime (Table 3), the observed longifolene diurnal pattern may simply reflect height of the boundary layer and intensity of vertical mixing.

Although its diurnal profile at $1.5 \mathrm{~m}$ (Fig. 3d) shows high mixing ratios at night, thus suggesting that its emissions are dependent on temperature, there is ample evidence that methyl chavicol emissions are best modeled as a light- and temperature-dependent emission process (see Bouvier-Brown et al., 2009b). For example, Bouvier-Brown et al. (2009b) showed a strong correlation between methyl chavicol and MBO in terms of diurnal profile and atmospheric lifetime, thus suggesting that the two compounds have a similar light- and temperature-dependent emissions mechanism.

\subsubsection{Light-dependent emissions}

The other sesquiterpenes with discernable diurnal trends appear to have light-dependent emissions. $\alpha$-Bergamotene, $\beta$-farnesene, as well as $\alpha$-farnesene, have similar sources (Bouvier-Brown et al., 2009a) and comparable estimated $\mathrm{OH}$ and ozone reaction rates (Table 3), so the discrepancies in their diurnal profiles can be attributed to differences in emission mechanisms. $\alpha$-Bergamotene and $\beta$-farnesene have higher mixing ratios during the daylight hours, suggesting that light plays a large role in their emissions (Fig. 3b). It is reasonable to suspect that the emissions of some sesquiterpene compounds are light-dependent because this emission model has been noted previously for the sesquiterpene $\beta$ caryophyllene (Hansen and Seufert, 2003; Duhl et al., 2008 and references therein). The mixing ratios of oxygenated terpene linalool follow the diurnal variation in PAR (Fig. 3e), indicating that light is essential for its emissions. Previous studies have also shown little or no emissions of linalool at night (e.g. Staudt et al., 1997; Staudt et al., 2000).

\subsection{Newly measured BVOC mass}

The quantification of the 6 sesquiterpenes, linalool, and methyl chavicol at the $1.5 \mathrm{~m}$ inlet adds an average of $0.87 \mu \mathrm{gC} \mathrm{m}^{-3}$ during the day (Table 4) and $1.2 \mu \mathrm{gC} \mathrm{m}^{-3}$ at night to the mass of carbon present in the atmosphere from BVOC emissions in the Blodgett Forest ecosystem. This is $28 \%$ and $13 \%$ of the monoterpene mass during the day
Table 4. Average daytime (10:00-17:00 PST) mixing ratios $(N=105)$ of BVOCs directly emitted by the Blodgett Forest ecosystem measured at $1.5 \mathrm{~m}$. Numbers in italics indicate that the average value is below the detection limit, while "NA" denotes that all values were below the detection limit.

\begin{tabular}{lrrr}
\hline BVOC & $\mathrm{ppt}$ & $\mu \mathrm{g}_{\mathrm{BVOC}} \mathrm{m}^{-3}$ & $\mu \mathrm{g}_{\mathrm{C}} \mathrm{m}^{-3}$ \\
\hline$\beta$-pinene & $311 \pm 250$ & 1.51 & 1.33 \\
3-carnene & $210 \pm 163$ & 1.02 & 0.90 \\
$\alpha$-pinene & $104 \pm 72$ & 0.51 & 0.45 \\
limonene & & & \\
$(+\beta$-phellandrene) & $76 \pm 46$ & 0.37 & 0.32 \\
myrcene & $10 \pm 5$ & 0.05 & 0.04 \\
camphene & $5.9 \pm 4.4$ & 0.03 & 0.03 \\
terpinolene & $3.5 \pm 2.2$ & 0.02 & 0.02 \\
$\gamma$-terpinene & $1.5 \pm 2.2$ & 0.007 & 0.006 \\
$\alpha$-terpinene & $\mathrm{NA}$ & $\mathrm{NA}$ & $\mathrm{NA}$ \\
sum monoterpenes & 722 & 3.50 & 3.09 \\
methyl chavicol & $127 \pm 99$ & 0.67 & 0.54 \\
linalool & $9.9 \pm 3.4$ & 0.05 & 0.04 \\
$\alpha$-bergamotene & $24 \pm 11$ & 0.18 & 0.15 \\
longifolene & $3.6 \pm 3.5$ & 0.03 & 0.03 \\
$\alpha$-farnesene & $9.4 \pm 8.2$ & 0.07 & 0.06 \\
$\beta$-farnesene & $6.0 \pm 5.6$ & 0.04 & 0.04 \\
SQT 9 & $0.9 \pm 1.7$ & 0.007 & 0.006 \\
SQT 10 & $0.5 \pm 1.8$ & 0.004 & 0.003 \\
sum sesquiterpenes & 44.5 & 0.32 & 0.29 \\
newly measured BVOCs & 181 & 1.1 & 0.87 \\
\hline & & & \\
\hline
\end{tabular}

and night, respectively. Among the newly measured species, methyl chavicol represents the highest mass fraction with $17 \%$ of the monoterpene mass during the day and $9.9 \%$ during the night.

Branch enclosure measurements, scaled to represent emissions of the entire ecosystem, as described by BouvierBrown et al. (2009a), show a large (33.8\%) sesquiterpene contribution to the total terpene + methyl chavicol emission mass (Fig. 4a). Conversely, the ambient air data show a small $(7.2 \%$ at $1.5 \mathrm{~m}$ and $1.1 \%$ at $9.3 \mathrm{~m})$ sesquiterpene mass contribution to total terpene + methyl chavicol mixing ratios (Fig. 4b). The discrepancy between the relative mixing ratios measured in the branch enclosures and that measured in ambient air must be due to more rapid chemical losses of the reactive semi-volatile sesquiterpene compounds for two reasons: 1) many sesquiterpenes observed in branch enclosure experiments cannot be detected in ambient air due to their rapid loss via oxidation. In fact, $\beta$-caryophyllene was never detected in the ambient air samples even though it was a major emission from manzanita branches (Bouvier-Brown et al., 2009a), and at last account, the percent leaf area contribution of each species to the ecosystem was $52 \%$ ponderosa pine, 29\% manzanita, and 19\% ceanothus in 2003. 2) Some of these highly reactive compounds may also fail to survive the sampling system: the two most reactive compounds in the liquid standard mixture, $\beta$-caryophyllene and 


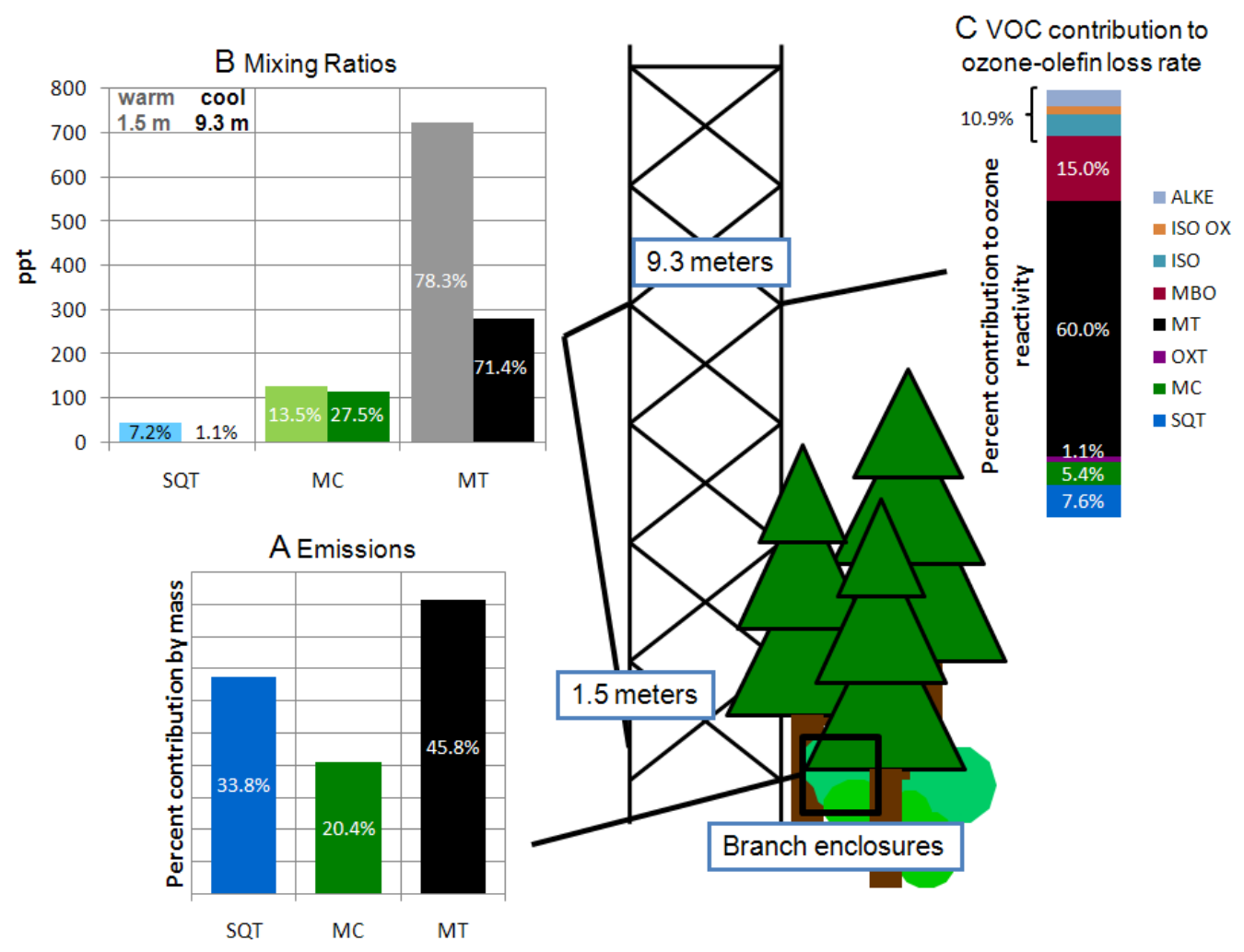

Fig. 4. (A) Percent contribution of SQT (sum of total sesquiterpenes), MC (methyl chavicol), and MT (sum of total monoterpenes) mass measured using branch enclosures (Bouvier-Brown et al., 2009a). (B) Average SQT, MC, and MT mixing ratios (ppt) from 10:00-17:00 PST measured at $1.5 \mathrm{~m}$ (light shade) and $9.3 \mathrm{~m}$ (dark shade) during BEARPEX. Percentages listed on each bar indicate the percent contribution by mass. Linalool is excluded because it only contributes $1 \%$ and $0.1 \%$ to the BVOC mass measured at $1.5 \mathrm{~m}$ and $9.3 \mathrm{~m}$, respectively. The $9.3 \mathrm{~m}$ data presented here correspond to measurements made during day of year 267-270 (24 September-27 September) when all VOC measurements were co-located (see also Bouvier-Brown et al., 2009b). (C) VOC percent contribution to total ozone-olefin loss rate at Blodgett Forest measured at $9.3 \mathrm{~m}$ from average VOC mixing ratios measured from 10:00-17:00 PST. OXT denotes the contribution of oxyterpene linalool. Additional VOCs include MBO (2-methyl-3-buten-2-ol), ISO (isoprene), ISO OX (methacrolein, methyl vinyl ketone, and 3-methyl furan), ALKE (alkenes, such as propene and ethene) measured over the same time period (day of year 267-270).

$\alpha$-humulene, had poor sample recovery (Table 2 ). The presence of oxidants in the sample lines would have a larger impact on sesquiterpenes due to their high reaction rates and their low mixing ratios. By comparing air samples with and without the presence of ozone, Hoffman (1995) showed that even with only $23 \mathrm{ppb}$ of ozone, there was $<5 \%$ recovery of $\beta$-caryophyllene and $\alpha$-humulene whereas $15 \%$ of $\alpha$-bergamotene was recovered. $\alpha$-Bergamotene has an estimated longer lifetime than either $\alpha$-humulene or $\beta$ caryophyllene (Table 3).

\subsection{Impact of BVOC on ecosystem oxidant loss rates}

Here we assess the average contribution of the newly measured BVOCs to the total above canopy ozone-olefin loss rate at Blodgett Forest $\left([\mathrm{VOC}] \times k_{\mathrm{O}_{3}}\right)$. Each compound's contribution to the average ozone-olefin loss rate was calculated using average daytime (10:00-17:00 PST) mixing ratios (to limit the influence of a changing boundary layer) measured at $9.3 \mathrm{~m}$ and known rate constants (Table 3). Rate constants not found in the literature were calculated based on chemical structure using the Environmental Protection Agency's Estimation Program Interface Suite (US EPA AOPWIN, 2000). Using estimates introduces uncertainty in the rate constants, particularly with $k_{\mathrm{O}_{3}}$. For example, the EPA estimate for $\beta$-caryophyllene and $\alpha$-humulene is 27 and 13 times slower than the literature values, respectively, but the estimate for longifolene is 23 times faster than the literature value. In addition to all of the compounds detailed in this manuscript, we also included VOC concentrations of $\mathrm{MBO}$, isoprene, isoprene oxidation products (methyl vinyl ketone (MVK), methacrolein (MACR), and 3-methylfuran), and alkenes, such as ethene and propene, that were measured by the NOAA GC-MS. The average mixing ratios measured from 10:00-17:00 PST from 24 September-27 September and the ozone rate coefficients of these VOCs are listed in Table 5 . 
Table 5. Average mixing ratios measured from 10:00-17:00 during day of year 267-270 (24 September-27 September) of volatile organic compounds measured by the NOAA GC-MS and their ozone reactivity. All rate constants are from Atkinson (2000) and references therein, except where noted.

\begin{tabular}{lrrr}
\hline VOC & $(\mathrm{ppt})$ & $k_{\mathrm{O}_{3}}\left(\mathrm{~cm}^{3} \mathrm{molec}^{-1} \mathrm{~s}^{-1}\right)$ & $\tau_{\mathrm{O}_{3}}{ }^{\mathrm{b}}(\mathrm{min})$ \\
\hline isoprene & $132 \pm 91$ & $1.3 \times 10^{-17}$ & $1.1 \times 10^{3}$ \\
methacrolein (MACR) & $103 \pm 62$ & $1.1 \times 10^{-18}$ & $1.2 \times 10^{4}$ \\
methyl vinyl ketone (MVK) & $100 \pm 97$ & $4.6 \times 10^{-18}$ & $3.1 \times 10^{3}$ \\
3-methylfuran & $5.3 \pm 2.4$ & $2.1 \times 10^{-17^{\mathrm{a}}}$ & 680 \\
2-methyl-3-buten-2-ol (MBO) & $459 \pm 174$ & $9.7 \times 10^{-18}$ & $1.5 \times 10^{3}$ \\
ethene & $111 \pm 30$ & $1.6 \times 10^{-18}$ & $8.9 \times 10^{3}$ \\
propene & $23 \pm 5$ & $1.0 \times 10^{-17}$ & $1.4 \times 10^{3}$ \\
\hline
\end{tabular}

a from Atkinson and Arey (2003)

${ }^{b}\left[\mathrm{O}_{3}\right]=1.18 \times 10^{12}$ molec cm $^{-3}(55 \mathrm{ppb})$

While methyl chavicol dominated the newly measured ambient BVOC mixing ratios and mass (Table 4; Fig. 4b), it has relatively little impact on the total ozone reactivity (Fig. 4c). Conversely, even the very small amount of linalool $(0.1 \%$ of mass at $9.3 \mathrm{~m}$ ) has a larger impact on the total ozone-olefin loss rate $(1.1 \%)$ relative to its mass contribution (Fig. 4c). More importantly, the small amount of sesquiterpenes quantified at $9.3 \mathrm{~m}$ significantly contributes to the overall ozoneolefin loss rate at Blodgett Forest. The newly measured BVOCs add $14 \%$ to the total ozone-olefin loss rate (Fig. 4c). $54 \%$ of this new reactivity is due to sesquiterpenes even though they only account for $4 \%(1.1 \% /(1.1 \%+27.5 \%))$ of the newly measured mass at $9.3 \mathrm{~m}$ (Fig. $4 \mathrm{~b}$ ). The contribution of highly reactive compounds to ozone-olefin loss rate calculated here is a lower limit considering that compounds such as $\beta$-caryophyllene were not adequately measured. Using emission rates and estimated ozone reaction rates $\left(k_{\mathrm{O}_{3}}\right)$ from Bouvier-Brown et al. (2009a), the sesquiterpene contribution to ozone loss at the point of emission is 2.4 (0.74 emission mass ratio $\mathrm{x} k_{\mathrm{O}_{3}}$ ratio $\mathrm{x}$ molecular weight ratio) times that of the monoterpene ratio. The impact of ozone loss due to sesquiterpenes above the canopy is much lower $(13 \%(7.6 \% / 30 \%)$ of the monoterpene contribution), but it is still a significant contribution.

Terpenes have a much larger impact on the ozone-olefin loss rate than the $\mathrm{OH}$ reactivity at Blodgett Forest. Together, the measured monoterpene, oxyterpene (linalool), sesquiterpene, and methyl chavicol mixing ratios make up $74 \%$ of the ozone-olefin loss rate (Fig. 4c) whereas these same compounds only contribute $\sim 17 \%$ to the total $\mathrm{OH}$ loss rate, of which the newly measured compounds contribute only $\sim 4 \%$ (J. Mao, personal communication, 2008). Little is known about the $\mathrm{NO}_{3}$ reactivity of newly-measured BVOCs, such as $\alpha$-bergamotene and methyl chavicol, and to our knowledge, there is no reliable way to estimate these $\mathrm{NO}_{3}$ reaction rate constants.

\subsection{Contribution to total organic aerosol}

Sesquiterpenes are oxidized rapidly in the forest canopy as a consequence of their reactivity, and a significant portion of their oxidized mass likely partitions into the aerosol phase. In order to assess their potential contribution to SOA, we estimate their potential ambient mixing ratio assuming loss due to reactivity did not occur. First, we assume the total sesquiterpene to total monoterpene mass ratio observed in the branch enclosures (0.74) is constant throughout the ecosystem during the warm conditions experienced during the branch enclosure measurements and the first half of BEARPEX. Using daytime (10:00-17:00 PST) averages and assuming sesquiterpenes should be $74 \%$ of the total monoterpene mixing ratio at $1.5 \mathrm{~m}$ (722 ppt, Table 4) gives a potential sesquiterpene mixing ratio of $356 \mathrm{ppt}$. Subtracting the sesquiterpenes actually measured $1.5 \mathrm{~m}(44.5 \mathrm{ppt})$ from the potential sesquiterpene mixing ratio $(356 \mathrm{ppt}) \mathrm{re}-$ veals a 312 ppt chemical loss. Removing this amount of sesquiterpene mass from the Blodgett Forest canopy is realistic given average canopy conditions of $\left[\mathrm{O}_{3}\right]=55 \mathrm{ppb}$ and an averaged ecosystem sesquiterpene reaction rate constant of $3.3 \times 10^{-15} \mathrm{~cm}^{3} \mathrm{molec}^{-1} \mathrm{~s}^{-1}$ (Bouvier-Brown et al., 2009a). Under these conditions, the average sesquiterpene lifetime is $\sim 4 \mathrm{~min}$, which is well within the estimated canopy residence time of 7-10 min (Kurpius and Goldstein, 2003; Farmer and Cohen, 2008), and only slightly longer than the $90 \mathrm{~s}$ between canopy air sweeps (exchange events) estimated by Holzinger et al. (2005). Although this estimate is based on a highly uncertain ozone reaction rate, the calculated lifetime is consistent with our measurements showing only small amounts of sesquiterpenes above the forest canopy. To the best of our knowledge, the SOA yields from some sesquiterpenes measured in this study, such as $\alpha$-bergamotene and $\alpha$-farnesene, have yet to be measured, so a $10-50 \%$ SOA yield is used in the following analysis. With this assumption, the sesquiterpene mass lost in the forest canopy must contribute $0.2-1.0 \mu \mathrm{g} \mathrm{m}^{-3}$ to the aerosol mass. This accounts for $6-32 \%$ of the average total organic aerosol 
mass $\left(3.10 \pm 2.06 \mu \mathrm{g} \mathrm{m}^{-3}\right.$, mean \pm standard deviation) measured by aerosol mass spectrometry (AMS) at BEARPEX (D. K. Farmer, K. S. Docherty, J. L. Jimenez, personal communication, 2008), where the high SOA yield estimate likely requires multiple oxidation steps. Using a similar analysis for the sesquiterpene contribution to SOA during the cool period at $9.3 \mathrm{~m}$ gives $0.07-0.36 \mu \mathrm{g} \mathrm{m}^{-3}$ of organic aerosol mass, or $2-12 \%$ of the average total organic aerosol mass.

\section{Conclusions}

We successfully modified an in-situ GC-MS instrument to quantify sesquiterpenes, linalool, methyl chavicol, and nopinone in ambient air with hourly time resolution. We report the first direct in-situ ambient air quantification of $\alpha$-bergamotene, longifolene, $\alpha$-farnesene, $\beta$-farnesene, and two unidentified sesquiterpenes. $\alpha$-Bergamotene dominated the daytime sesquiterpene mixing ratios. $\alpha$-Farnesene emissions are shown to be dependent on temperature, and $\alpha$ bergamotene and $\beta$-farnesene emissions are shown to also be light-dependent. While branch enclosure measurements reveal a very large sesquiterpene contribution (33.8\%) to the BVOC emission mass of total terpene plus methyl chavicol (Bouvier-Brown et al., 2009a), the small relative sesquiterpene mass contribution in ambient air reveals significant chemical loss before these compounds escape the forest canopy due to their high reactivity. These data provide a strong corroboration of previous evidence that oxidation products are abundant within the forest canopy, but remain poorly characterized. Even with the small amounts of sesquiterpene mass quantified at $9.3 \mathrm{~m}$, these compounds contribute $7.6 \%$ to the overall above canopy ozone-olefin loss rate at Blodgett Forest. Assuming sesquiterpeneto-monoterpene emission ratios during warm temperatures should reflect data from branch enclosure experiments, the sesquiterpenes oxidized in the forest canopy lead to formation of $6-32 \%$ of the total organic aerosol mass measured during BEARPEX.

Acknowledgements. This research was supported by the National Science Foundation Atmospheric Chemistry Program under grant 0443448. We thank Sierra Pacific Industries for the use of their land, the University of California, Berkeley, Center for Forestry, Blodgett Forest Research Station for cooperation in facilitating this research, and David Worton for manuscript review and enlightening discussions.

Edited by: A. B. Guenther

\section{References}

Andreae, M. O. and Crutzen, P. J.: Atmospheric aerosols: Biogeochemical sources and role in atmospheric chemistry, Science, 276, 1052-1058, 1997.

Atkinson, R.: Atmospheric chemistry of VOCs and $\mathrm{NO}_{\mathrm{x}}$, Atmos. Environ., 34, 2063-2101, 2000.

Atkinson, R. and Arey, J.: Gas-phase tropospheric chemistry of biogenic volatile organic compounds: A review, Atmos. Environ., 37, S197-S219, 2003.

Bauer, M. R., Hultman, N. E., Panek, J. A., and Goldstein, A. H.: Ozone deposition to a ponderosa pine plantation in the Sierra Nevada Mountains (CA): A comparison of two different climatic years, J. Geophys. Res., 105, 22123-22136, 2000.

Bonn, B., Hirsikko, A., Hakola, H., Kurtén, T., Laakso, L., Boy, M., Dal Maso, M., Mäkelä, J. M., and Kulmala, M.: Ambient sesquiterpene concentration and its link to air ion measurements, Atmos. Chem. Phys., 7, 2893-2916, 2007, http://www.atmos-chem-phys.net/7/2893/2007/.

Bouvier-Brown, N. C., Holzinger, R., Palitzsch, K., and Goldstein A. H.: Quantifying sesquiterpene and oxygenated terpene emissions from live vegetation using solid-phase microextraction fibers, J. Chromatogr. A, 1161, 113-120, 2007.

Bouvier-Brown, N. C., Holzinger, R., Palitzsch, K., and Goldstein, A. H.: Large emissions of sesquiterpenes and methyl chavicol quantified from branch enclosure measurements, Atmos. Environ., 43, 389-401, 2009a.

Bouvier-Brown, N. C., Goldstein, A. H., Worton, D. R., Matross, D. M., Gilman, J. B., Kuster, W. C., Welsh-Bon, D., Warneke, C., de Gouw, J. A., Cahill, T. M., and Holzinger, R.: Methyl chavicol: characterization of its biogenic emission rate, abundance, and oxidation products in the atmosphere, Atmos. Chem. Phys., 9, 2061-2074, 2009b, http://www.atmos-chem-phys.net/9/2061/2009/.

Boy, M., Karl, T., Turnipseed, A., Mauldin, R. L., Kosciuch, E., Greenberg, J., Rathbone, J., Smith, J., Held, A., Barsanti, K., Wehner, B., Bauer, S., Wiedensohler, A., Bonn, B., Kulmala, M., and Guenther, A.: New particle formation in the Front Range of the Colorado Rocky Mountains, Atmos. Chem. Phys., 8, 15771590, 2008, http://www.atmos-chem-phys.net/8/1577/2008/.

Calogirou, A., Jensen, N. R., Nielsen, C. J., Kotzias, D., and Hjorth, J.: Gas-phase reactions of nopinone, 3-isopropenyl6-oxo-heptanal, and 5-methyl-5-vinyltetrahydrofuran-2-ol with $\mathrm{OH}, \mathrm{NO}_{3}$, and ozone, Environ. Sci. Technol., 33, 453-460, 1999.

Ciccioli, P., Brancaleoni, E., Frattoni, M., Di Palo, V., Valentini, R., Tirone, G., Seufert, G., Bertin, N., Hansen, U., Csiky, O., Lenz, R., and Sharma, M.: Emission of reactive terpene compounds from orange orchards and their removal by within-canopy processes, J. Geophys. Res., 104(D7), 8077-8094, 1999.

Di Carlo, P., Brune, W. H., Martinez, M., Harder, H., Lesher, R., Ren, X., Thornberry, T., Carroll, M. A., Young, V., Shepson, P. B., Riemer, D., Apel, E., and Campbell, C.: Missing OH reactivity in a forest: Evidence for unknown reactive biogenic VOCs, Science, 304, 722-725, 2004.

Duhl, T. R., Helmig, D., and Guenther, A.: Sesquiterpene emissions from vegetation: a review, Biogeosciences, 5, 761-777, 2008, http://www.biogeosciences.net/5/761/2008/.

Farmer, D. K. and Cohen, R. C.: Observations of $\mathrm{HNO}_{3}, \sum \mathrm{AN}$, $\sum \mathrm{PN}$ and $\mathrm{NO}_{2}$ fluxes: evidence for rapid $\mathrm{HO}_{\mathrm{x}}$ chemistry within 
a pine forest canopy, Atmos. Chem. Phys., 8, 3899-3917, 2008, http://www.atmos-chem-phys.net/8/3899/2008/.

Fuentes, J. D., Lerdau, M., Atkinson, R., Baldocchi, D., Bottenheim, J. W., Ciccioli, P., Lamb, B., Geron, C., Gu, L., Guenther, A., Sharkey, T. D., and Stockwell, W.: Biogenic hydrocarbons in the atmospheric boundary layer: A review, B. Am. Meteorol. Soc., 81, 1537-1575, 2000.

Goldan, P. D., Kuster, W. C., Williams, E., Murphy, P. C., Fehsenfeld, F. C., and Meagher, J.: Nonmethane hydrocarbon and oxy hydrocarbon measurements during the 2002 New England Air Quality Study, J. Geophys. Res., 109, D21309, doi:10.1029/2003JD004455, 2004.

Goldstein, A. H., Hultman, N. E., Fracheboud, J. M., Bauer, M. R., Panek, J. A., Xu, M., Qi, Y., Guenther, A. B., and Baugh, W.: Effects of climate variability on the carbon dioxide, water, and sensible heat fluxes above a ponderosa pine plantation in the Sierra Nevada (CA), Agr. Forest Meteorol., 101, 113-129, 2000.

Goldstein, A. H., McKay, M., Kurpius, M. R., Schade, G. W., Lee, A., Holzinger, R., and Rasmussen, R. A.: Forest thinning experiment confirms ozone deposition to forest canopy is dominated by reaction with biogenic VOCs, Geophys. Res. Lett., 31, L22106, doi:10.1029/2004GL021259, 2004.

Goldstein, A. H. and Galbally, I. E.: Known and unexplored organic constituents in the earth's atmosphere, Environ. Sci. Technol., 41, 1514-1521, 2007.

Griffin, R. J., Cocker III, D. R., Flagan, R. C., and Seinfeld, J. H.: Organic aerosol formation from the oxidation of biogenic hydrocarbons, J. Geophys. Res., 104(D3), 3555-3567, 1999.

Guenther, A. B., Zimmerman, P. R., Harley, P. C., Monson, R. K., and Fall, R.: Isoprene and monoterpene emission rate variability - Model evaluations and sensitivity analyses, J. Geophys. Res., 98, 12609-12617, 1993.

Hansen, U. and Seufert, G.: Temperature and light dependence of $\beta$-caryophyllene emission rates, J. Geophys. Res., 108(D24), 4801, doi:10.1029/2003JD003853, 2003.

Heald, C. L., Henze, D. K., Horowitz, L. W., Feddema, J., Lamarque, J.-F., Guenther, A., Hess, P. G., Vitt, F., Seinfeld, J. H., Goldstein, A. H., and Fung, I.: Predicted change in global secondary organic aerosol concentrations in response to future climate, emissions, and land use change, J. Geophys. Res., 113, D052211, doi:10.1029/2007JD009092, 2008.

Helmig, D., Revermann, T., Pollmann, J., Kaltschmidt, O., Hernandez, A. J., Bocquet, F., and David, D.: Calibration system and analytical considerations for quantitative sesquiterpene measurements in air, J. Chromatogr. A, 1002, 193-211, 2003.

Helmig, D., Bocquet, F., Pollmann, J., and Revermann, T.: Analytical techniques for sesquiterpene emission rate studies in vegetation enclosure experiments, Atmos. Environ., 38, 557-572, 2004.

Hoffmann, T.: Adsorptive preconcentration technique including oxidant scavenging for the measurement of reactive natural hydrocarbons in ambient air, Fresenius' J. Anal. Chem., 351, 41-47, 1995.

Hoffmann, T., Odum, J., Bowman, F., Collins, D., Klockow, D., Flagan, R. C., and Seinfeld, J. H.: Aerosol formation potential of biogenic hydrocarbons, J. Aerosol Sci., 27, S233-S234, 1996.

Holzinger, R., Lee, A., Paw U., K. T., and Goldstein, U. A. H.: Observations of oxidation products above a forest imply biogenic emissions of very reactive compounds, Atmos. Chem. Phys., 5,
$67-75,2005$,

http://www.atmos-chem-phys.net/5/67/2005/.

Jaoui, M. and Kamens, R. M.: Gas and particulate products distribution from the photooxidation of $\alpha$-humulene in the presence of $\mathrm{NO}_{\mathrm{x}}$, natural atmospheric air and sunlight, J. Atmos. Chem., 46, 29-54, 2003.

Jaoui, M., Leungsakul, S., and Kamens, R. M.: Gas and particle products distribution from the reaction of $\beta$-caryophyllene with ozone, J. Atmos. Chem., 45, 261-287, 2003.

Kourtchev, I., Bejan, I., Sodeau, J. R., and Wenger, J. C.: Gas-phase reaction of $(E)-\beta$-farnesene with ozone: Rate coefficient and carbonyl products, Atmos. Environ., 43, 3182-3190, 2009.

Kurpius, M. R. and Goldstein, A. H.: Gas-phase chemistry dominates $\mathrm{O}_{3}$ loss to a forest, implying a source of aerosols and hydroxyl radicals to the atmosphere, Geophys. Res. Lett., 30, 1371, doi:10.1029/2002GL016785, 2003.

Lamanna, M. S. and Goldstein, A. H.: In situ measurements of $\mathrm{C}_{2}-\mathrm{C}_{10}$ volatile organic compounds above a Sierra Nevada ponderosa pine plantation, J. Geophys. Res., 104, 21247-21262, 1999.

Lee, A., Schade, G. W., Holzinger, R., and Goldstein, A. H.: A comparison of new measurements of total monoterpene flux with improved measurements of speciated monoterpene flux, Atmos. Chem. Phys., 5, 505-513, 2005,

http://www.atmos-chem-phys.net/5/505/2005/.

Levis, S., Wiedinmyer, C., Bonan, G. B., and Guenther, A.: Simulating biogenic volatile organic compound emissions in the Community Climate System Model, J. Geophys. Res., 108(D21), 4659, doi:10.1029/2002JD003203, 2003.

Millet, D. B., Donahue, N. M., Pandis, S. N., Polidori, A., Stanier, C. O., Turpin, B. J., and Goldstein, A. H.: Atmospheric volatile organic compound measurements during the Pittsburgh Air Quality Study: Results, interpretation, and quantification of primary and secondary contributions, J. Geophys. Res., 110, D07S07, doi:10.1029/2004JD004601, 2005.

Ortega, J. and Helmig, D.: Approaches for quantifying reactive and low-volatility biogenic organic compound emissions by vegetation enclosure techniques - Part A, Chemosphere, 72, 343-364, 2008.

Owen, S. M., Boissard, C., and Hewitt, C. N.: Volatile organic compounds (VOCs) emitted from 40 Mediterranean plant species: VOC speciation and extrapolation to habitat scale, Atmos. Environ., 35, 5393-5409, 2001.

Pollmann, J., Ortega, J., and Helmig, D.: Analysis of atmospheric sesquiterpenes: Sampling losses and mitigation of ozone interferences, Environ. Sci. Technol., 39, 9620-9629, 2005.

Sakulyanontvittaya, T., Duhl, T., Wiedinmyer, C., Helmig, D., Matsunaga, S., Potosnak, M., Milford, J., and Guenther, A.: Monoterpene and sesquiterpene emission estimates for the United States, Environ. Sci. Technol., 42, 1623-1629, 2008.

Saxton, J. E., Lewis, A. C., Kettlewell, J. H., Ozel, M. Z., Gogus, F., Boni, Y., Korogone, S. O. U., and Serça, D.: Isoprene and monoterpene measurements in a secondary forest in northern Benin, Atmos. Chem. Phys., 7, 4095-4106, 2007, http://www.atmos-chem-phys.net/7/4095/2007/.

Schade, G. W., Goldstein, A. H., and Lamanna, M. S.: Are monoterpene emissions influenced by humidity?, Geophys. Res. Lett., 26 , 2187-2190, 1999.

Schade, G. W., Goldstein, A. H., Gray, D. W., and Lerdau, M. T. 
Canopy and leaf level 2-methyl- 3-buten-2-ol fluxes from a ponderosa pine plantation, Atmos. Environ., 34, 3535-3544, 2000.

Schade, G. W. and Goldstein, A. H.: Increase of monoterpene emissions from a pine plantation as a result of mechanical disturbances, Geophys. Res. Lett., 30, 1380, doi:10.1029/2002GL016138, 2003.

Staudt, M., Bertin, N., Hansen, U., Seufert, G., Ciccioli, P., Foster, P., Frenzel, B., and Fugit, J.-L.: Seasonal and diurnal patterns of monoterpene emissions from Pinus pinea (L.) under field conditions, Atmos. Environ., 31, 145-156, 1997.
Staudt, M., Bertin, N., Frenzel, B., and Seufert, G.: Seasonal variation in amount and composition of monoterpenes emitted by young Pinus pinea trees - Implications for emission modeling, J. Atmos. Chem., 35, 77-99, 2000.

US EPA, M.1.: Estimation Programs Interface Suite for Microsoft Windows, AOPWIN v.1.92, United States Environmental Protection Agency, Washington DC, USA, 2000. 